\title{
HLA antigens in donovanosis (granuloma inguinale)
}

\author{
Nigel O'Farrell, Michael Hammond
}

\begin{abstract}
Objective-To compare the frequencies of HLA antigens in patients with donovanosis and in controls.

Design-HLA Class I, Class II and DQ antigens were detected in patients with genital ulceration caused by donovanosis and in a control group.

Setting-City Health STD Clinic, King Edward VIII Hospital, Durban, South Africa.

Participants-Sixty (47 men, 13 women) patients with donovanosis.

Results-HLA B57 was detected in nine of 60 (15\%) with donovanosis and 75 of $1478(5 \cdot 1 \%)$ controls $\left(\mathbf{R R}=3.3 \chi^{2}=11.0, p=0.001, \mathbf{p}\right.$ corrected $=0.026$ ).

Conclusions-A possible link between donovanosis and HLA B57 could be explained by coexisting alleles or immune response genes in linkage disequilibrium altering disease susceptibility.
\end{abstract}

\section{Introduction}

Donovanosis is a genital ulcerative disease (GUD) found in diverse geographical locations where poor socio-economic conditions prevail and is commoner in dark-skinned races. ${ }^{1}$ Donovanosis is generally regarded as a sexually transmitted disease (STD) but the modes of infection and transmission are not yet established with certainty. The causative agent, Calymmatobacterium granulomatis, has been isolated from faeces, and transmission through auto-inoculation is suggested. ${ }^{2}$ The organism possesses a capsule and is similar to klebsiella strains but its biochemical and bacterial characteristics are not well defined. ${ }^{3}$

Although previously thought to be uncommon in Southern Africa, donovanosis has recently emerged as a significant cause of GUD in Durban. In $1988^{4} 171$ cases were diagnosed by the presence of Donovan bodies on direct microscopy using the RapiDiff technique, ${ }^{5}$ a simple bench diagnostic staining method.

City Health STD Department, King Edward VIII Hospital, Congella, Durban, South Africa Nigel O'Farrell

Transplantation Unit, Natal Institute of Immunology, Pinetown, Natal, South Africa

Michael Hammond
Most bacterial STDs are readily transmitted from male to female and female to male. However, variable transmission rates of infection with $C$ granulomatis are reported from different populations. The prevalence of disease amongst regular sexual partners varies from $1 \%$ in the USA ${ }^{6}$ and $1 \%$ in Papua and New Guinea ${ }^{7}$ to $50 \%$ in India. ${ }^{8}$ The apparent racial predominance amongst blacks and variability in transmission suggests that host susceptibility factors may be relevant in the disease process.

No clear association between a single HLA antigen and a particular STD has been described but donovanosis has been suggested as one STD with a reasonable chance of such a link..$^{9}$ We therefore investigated the frequency of HLA antigens amongst Zulu patients with donovanosis attending a STD clinic in Durban.

\section{Patients and Methods}

Sixty Zulu patients ( 47 men, 13 women) attending the City Health STD Clinic at King Edward VIII Hospital, Durban with genital ulcerative lesions of donovanosis were entered into the study. Donovanosis was diagnosed by the detection of Donovan bodies on tissue smears stained with RapiDiff ${ }^{5}$ and examined by direct microscopy. Specific (TPHA) and non-specific (RPR) serological tests for syphilis were performed. Laboratory facilities for identifying herpes simplex virus, chancroid and lymphogranuloma venereum infections were unavailable.

The control group consisted of 1478 normal subjects who were either staff or randomly selected blood donors of the same ethnic origins as the patients. HLA Class I antigens were determined in all patients and control subjects by a two-stage microlymphocytotoxicity test ${ }^{10}$ with 180 sera consisting of: 1 . local sera requested for use in international histocompatibility workshops; 2 . local sera verified with international workshop sera; 3 . sera exchanged with other laboratories worldwide.

Similarly 120 sera were used to define the Class II antigens on B-lymphocyte enriched lymphocyte suspension prepared with the aid of straws packed with nylon wool. ${ }^{11}$ Class II antigens were determined in 53 patients and 513 controls except that HLA DQ antigens were tested in 129 controls.

\section{Statistics}

Differences in HLA frequencies were tested for significance with the $\chi^{2}$ test and the probability 
Table 1 Frequency of HLA Class I antigens in patients with donovanosis and normal controls

\begin{tabular}{|c|c|c|c|c|c|c|}
\hline \multirow[b]{2}{*}{$H L A$} & \multicolumn{2}{|l|}{ Controls } & \multicolumn{2}{|c|}{ Donovanosis } & \multirow[b]{2}{*}{$\chi^{2}$} & \multirow{2}{*}{$\begin{array}{l}\text { Relative } \\
\text { risk }\end{array}$} \\
\hline & $N=1478$ & $(\%)$ & $N=$ & $D(\%)$ & & \\
\hline $\begin{array}{l}\text { A1 } \\
\text { A36 } \\
\text { A2 } \\
\text { A3 } \\
\text { A23 } \\
\text { A24 } \\
\text { A25 } \\
\text { A26 } \\
\text { A34 } \\
\text { A28 } \\
\text { A29 } \\
\text { A30 } \\
\text { A31 } \\
\text { A32 } \\
\text { A33 } \\
\text { A43 } \\
\text { A66 }\end{array}$ & $\begin{array}{r}123 \\
12 \\
358 \\
165 \\
281 \\
81 \\
55 \\
173 \\
124 \\
319 \\
213 \\
455 \\
57 \\
28 \\
58 \\
2 \\
1\end{array}$ & $\begin{array}{r}(8.32) \\
(0.81) \\
(24.22) \\
(11 \cdot 16) \\
(19.01) \\
(5.48) \\
(3.72) \\
(11.71) \\
(8.39) \\
(21.58) \\
(14.41) \\
(30.78) \\
(3.86) \\
(1.89) \\
(3.92) \\
(0.14) \\
(0.07)\end{array}$ & $\begin{array}{r}3 \\
1 \\
15 \\
12 \\
3 \\
6 \\
0 \\
5 \\
6 \\
21 \\
7 \\
16 \\
3 \\
2 \\
2 \\
0 \\
0\end{array}$ & $\begin{array}{c}(5.00) \\
(1.67) \\
(25.0) \\
(20.0) \\
(5.00) \\
(10.00) \\
(0.00) \\
(8.33) \\
(10.00) \\
(35.00) \\
(11.67) \\
(26.67) \\
(5.00) \\
(3.33) \\
(3.33) \\
(0.00) \\
(0.00)\end{array}$ & $\begin{array}{l}0.85 \\
0.50 \\
0.02 \\
4.42 \\
7.52 \\
2.21 \\
2.32 \\
0.64 \\
0.19 \\
6.03 \\
0.35 \\
0.46 \\
0.20 \\
0.62 \\
0.05 \\
0.08 \\
0.04\end{array}$ & $\begin{array}{l}0.6 \\
2.1 \\
1.0 \\
2.0 \\
0.2 \\
1.9 \\
0.0 \\
0.7 \\
1.2 \\
2.0 \\
0.8 \\
0.8 \\
1.3 \\
1.8 \\
0.8 \\
0.0 \\
0.0\end{array}$ \\
\hline $\begin{array}{l}\text { B7 } \\
\text { B8 } \\
\text { B13 } \\
\text { B14 } \\
\text { B18 } \\
\text { B21 } \\
\text { B22 } \\
\text { B27 } \\
\text { B35 } \\
\text { B37 } \\
\text { B38 } \\
\text { B39 } \\
\text { B41 } \\
\text { B42 } \\
\text { B44 } \\
\text { B45 } \\
\text { B47 } \\
\text { B48 } \\
\text { B51 } \\
\text { B52 } \\
\text { B53 } \\
\text { B57 } \\
\text { B58 } \\
\text { B60 } \\
\text { B62 } \\
\text { B63 } \\
\text { B70 }\end{array}$ & $\begin{array}{r}348 \\
189 \\
45 \\
88 \\
80 \\
29 \\
1 \\
5 \\
109 \\
2 \\
29 \\
24 \\
27 \\
296 \\
233 \\
139 \\
1 \\
1 \\
16 \\
20 \\
20 \\
75 \\
471 \\
1 \\
10 \\
40 \\
407\end{array}$ & $\begin{array}{r}(23.55) \\
(12.79) \\
(3.04) \\
(5.95) \\
(5.41) \\
(1.96) \\
(0.07) \\
(0.34) \\
(7.37) \\
(0.14) \\
(1.96) \\
(1.62) \\
(1.83) \\
(20.03) \\
(15.76) \\
(9.40) \\
(0.07) \\
(0.07) \\
(1.08) \\
(1.35) \\
(1.35) \\
(5.07) \\
(31.87) \\
(0.07) \\
(0.68) \\
(2.71) \\
(27.54)\end{array}$ & $\begin{array}{r}15 \\
10 \\
1 \\
1 \\
1 \\
2 \\
0 \\
0 \\
8 \\
0 \\
2 \\
1 \\
2 \\
12 \\
11 \\
1 \\
0 \\
0 \\
0 \\
2 \\
2 \\
9 \\
21 \\
0 \\
0 \\
1 \\
9\end{array}$ & $\begin{array}{r}(25.00) \\
(16.67) \\
(1.67) \\
(1.67) \\
(1.67) \\
(3.33) \\
(0.00) \\
(0.00) \\
(13.33) \\
(0.00) \\
(3.33) \\
(1.67) \\
(3.33) \\
(20.00) \\
(18.33) \\
(1.67) \\
(0.00) \\
(0.00) \\
(0.00) \\
(3.33) \\
(3.33) \\
(15.00) \\
(35.00) \\
(0.00) \\
(0.00) \\
(1.67) \\
(15.00)\end{array}$ & $\begin{array}{r}0.07 \\
0.77 \\
0.38 \\
1.94 \\
1.62 \\
0.55 \\
0.04 \\
0.20 \\
2.91 \\
0.08 \\
0.55 \\
0.00 \\
0.71 \\
0.00 \\
0.29 \\
4.17 \\
0.04 \\
0.04 \\
0.66 \\
1.60 \\
1.60 \\
11.00 \\
0.26 \\
0.04 \\
0.41 \\
0.24 \\
4.59\end{array}$ & $\begin{array}{l}1 \cdot 1 \\
1.4 \\
0.5 \\
0.3 \\
0.3 \\
1.7 \\
0.0 \\
0.0 \\
1.9 \\
0.0 \\
1.7 \\
1.0 \\
1.9 \\
1.0 \\
1.2 \\
0.2 \\
0.0 \\
0.0 \\
0.0 \\
2.5 \\
2.5 \\
3.3 \\
1.2 \\
0.0 \\
0.0 \\
0.6 \\
0.5\end{array}$ \\
\hline
\end{tabular}

corrected by multiplying the $\mathrm{p}$ value by the number of comparisons made, that is, the number of antigens tested. ${ }^{12}$ Relative risks were calculated according to the formulae recommended by Woolf. ${ }^{13}$

\section{Results}

The frequencies of HLA A and B antigens in the patients and controls are shown in table 1 and of HLA DR and DQ antigens in table 2. HLA B57 was detected in nine of $60(15 \%)$ with donovanosis and 75 of $1478(5 \cdot 1 \%)$ controls $\left(R R=3 \cdot 3, \chi^{2}=11 \cdot 0, p=\right.$ $0.001, p$ corrected $=0.026)$. HLA A23 was detected in three of $60(5 \%)$ with donovanosis and 281 of 1478 $(19.0 \%)$ controls $\left(R R=0.2, \chi^{2}=7.5, p<0.01, p\right.$ not significant after correction).

Positive serological tests for syphilis (TPHA and RPR were detected in 14 (10 men and four women).
Table 2 Frequency of HLA Class II antigens in patients with donovanosis and normal controls

\begin{tabular}{|c|c|c|c|c|c|c|}
\hline \multirow[b]{2}{*}{$H L A$} & \multicolumn{2}{|l|}{ Controls } & \multicolumn{2}{|c|}{ Donovanosis } & \multirow[b]{2}{*}{$\chi^{2}$} & \multirow{2}{*}{$\begin{array}{l}\text { Relative } \\
\text { risk }\end{array}$} \\
\hline & $N=513$ & $(\%)$ & \multicolumn{2}{|c|}{$N=53(\%)$} & & \\
\hline DR1 & 24 & $(4 \cdot 68)$ & 1 & $(1 \cdot 89)$ & 0.89 & 0.4 \\
\hline DR2 & 124 & $(24 \cdot 17)$ & 16 & $(30 \cdot 19)$ & 0.93 & $1 \cdot 4$ \\
\hline DR3 & 181 & $(35 \cdot 28)$ & 23 & $(43 \cdot 40)$ & $1 \cdot 37$ & $1 \cdot 4$ \\
\hline DR4 & 49 & $(9.55)$ & 3 & $(5 \cdot 66)$ & 0.87 & 0.6 \\
\hline DR5 & 165 & $(32 \cdot 16)$ & 12 & $(22 \cdot 64)$ & $2 \cdot 03$ & 0.6 \\
\hline DR6 & 92 & $(17 \cdot 93)$ & 6 & $(11 \cdot 32)$ & $1 \cdot 47$ & 0.6 \\
\hline DR7 & 79 & $(15 \cdot 40)$ & 10 & $(18 \cdot 87)$ & 0.44 & $1 \cdot 3$ \\
\hline DR8 & 20 & $(3.90)$ & 3 & $(5 \cdot 66)$ & $0 \cdot 38$ & $1 \cdot 5$ \\
\hline DR9 & 4 & $(0.78)$ & 2 & $(3 \cdot 77)$ & $4 \cdot 11$ & $5 \cdot 0$ \\
\hline DR 10 & 11 & $(2 \cdot 14)$ & 4 & $(7 \cdot 55)$ & $5 \cdot 44$ & $3 \cdot 7$ \\
\hline & $N=176$ & & $N=$ & & & \\
\hline DQW1 & 122 & $(69 \cdot 32)$ & 36 & $(67 \cdot 92)$ & 0.04 & 0.9 \\
\hline DQWW2 & 59 & $(33.52)$ & 21 & $(39 \cdot 62)$ & 0.67 & $1 \cdot 3$ \\
\hline DQW3 & 42 & $(23.86)$ & 16 & $(30 \cdot 19)$ & 0.86 & $1 \cdot 4$ \\
\hline
\end{tabular}

\section{Discussion}

There are few reports linking HLA antigens and STDs. Amongst Chinese prostitutes in Singapore HLA AW19 and HLA B17 were associated with syphilis and gonorrhoea and HLA A11 and HLA B15 conferred relative resistance. ${ }^{14}$ Behcet's disease, although not a STD, does cause genital ulceration and is associated with HLA B5. ${ }^{15}$ The development of disease may be related to early sexual intercourse or adolescent infection. ${ }^{16}$ Our findings of a possible link between HLA B57 and donovanosis and a trend towards resistance to disease with HLA A23 could be explained by co-existing alleles or immune response genes in linkage disequilibrium altering disease susceptibility.

Donovanosis is a STD about which little is known despite its recognition in the nineteenth century. It differs from most bacterial STDs in having a long incubation period and a variable transmission rate to regular sexual partners thereby suggesting inherent differences in host susceptibility. The causative organism $C$ granulomatis shares some features of klebsiella strains including a prominent capsule but its bacterial characteristics are still not yet clearly defined. Klebsiella extracts are more likely to interact with HLA B27 than other HLA antigens producing an altered-self major histocompatibility complex that may trigger reactive arthritis. ${ }^{17}$

Donovanosis has only recently been recognised as a significant cause of GUD amongst the local Zulu population. ${ }^{4}$ Whether this reflects a new epidemic or increased awareness following the introduction of a rapid diagnostic test is uncertain. Elsewhere in South Africa donovanosis occurs in East Transvaal amongst the Swazis ${ }^{18}$ but is otherwise uncommon.

The highest prevalence of donovanosis worldwide is in Dutch New Guinea and Papua New Guinea. ${ }^{19}$ However, HLA B57 was not identified amongst 
natives of the Highlands and Coastal Areas. ${ }^{20}$ Further studies of HLA status and donovanosis are required amongst population groups from endemic areas to clarify possible immunopathological mechanisms of disease and assess the role of genetic factors.

Address for correspondence: Dr Nigel O'Farrell, Lydia Department, St Thomas' Hospital, London SEI 7RH, UK.

1 D'Aunoy R, von Haam E. Granuloma inguinale. Am J Trop Med 1937; 17:747-63.

2 Goldberg J. Studies on granuloma inguinale: VII. Some epidemiological considerations of the disease. $\mathrm{Br} J$ Venereal Dis 1964;40:140-5.

3 Kuberski T. Granuloma inguinale (Donovanosis). Sex Transm Dis 1980;7:29-36.

4 O'Farrell N. Donovanosis (Granuloma inguinale) in Durban: a risk factor for HIV-1 in men. MSSVD Spring Meeting. 30 May-2 June 1991, Heidelberg, West Germany.

5 O'Farrell N, Hoosen AA, Coetzee K, van den Ende J. A rapid stain for the diagnosis of granuloma inguinale (Donovanosis). Genitourin Med 1990;66:200-1.

6 Packer H, Goldberg J. Studies of the antigenic relationship of D granulomatis to members of the tribe Escherichiae. $A m J$ Syphilis 1950;34:343-50.

7 Maddocks I, Anders EM, Dennis E. Donovanosis in Papua New Guinea. Br J Venereal Dis 1976;52:190-6.

$8 \mathrm{Lal} \mathrm{S}$, Nicholas C. Epidemiological and clinical features in 165 cases of granuloma inguinale. $\mathrm{Br} J$ Venereal Dis 1970;46: 461-3.
9 Kuberski T. Histocompatibility antigens and the sexually transmitted diseases. Sex Transm Dis 1980;7:203-5.

10 Terasaki PI, McClelland JD. Microdroplet assay of human serum cytotoxins. Nature 1964;204:998-1000.

11 Danilovs JA, Ayoub G, Terasaki PI. B lymphocyte isolation by thrombin-nylon wool. In: Terasaki PI, Ed. Histocompatibility Testing 1980. Los Angeles, University of California Press, 1980.

12 Svejgaard A, Jersild C, Nielsen LC, Bodmer WF. HLA antigens and disease: statistical and genetical considerations. Tissue Antigens 1974;4:95-105.

13 Woolf $\mathrm{B}$. On estimating the relation between blood group and disease. Ann Hum Gen 1955;19:251-3.

14 Chan SH, Tan T, Kamarudin A, Wee GB, Rajan VS. HLA and sexually transmited diseases in prostitutes. $\mathrm{Br} J$ Venereal Dis 1979;55:207-10.

15 Ersoy F, Berkel I, Firat T, Kazokoglu H. HLA antigens associated with Behcet's disease. Arch Dermatol 1977;113:1720-1

16 Cooper C, Pippard EC, Sharp H, Wickham C, Chamberlain MA, Barker DJP. Is Behcet's disease triggered by childhood infection? Ann Rheum Dis 1989;48:421-3.

17 Batchelor JR, Welsh KI. Association of HLA antigens with disease. In: Lachmann PJ, Peters DK, eds. Clinical Aspects of Immunology, Vol 1, Oxford: Blackwell Scientific Publications, 1982 .

18 Wistrand R, Wegerhoff F. Granuloma inguinale in the Eastern Transvaal. $S$ Afr Med J 1985;67:13-15.

19 Vogel LC, Richens J. Donovanosis in Dutch South New Guinea: History, evolution of the epidemic and control. Papua New Guinea Med J 1989;32:203-18.

20 Crane G, Bhatia K, Honeyman M, et al. HLA studies of Highland and Coastal New Guineans. Hum Immunol 1985;12:247-60.

Accepted for publication 1 August 1991 